\title{
Phytopathology
}

\section{Rathayibacter toxicus, Other Rathayibacter Species Inducing Bacterial Head Blight of Grasses, and the Potential for Livestock Poisonings}

\author{
Timothy D. Murray, Brenda K. Schroeder, William L. Schneider, Douglas G. Luster, Aaron Sechler, \\ Elizabeth E. Rogers, and Sergei A. Subbotin
}

First author: Department of Plant Pathology, Washington State University, Pullman, WA 99164; second author: Entomology, Plant Pathology and Nematology, University of Idaho, Moscow, ID 83844; third, fourth, fifth, and sixth authors: U.S. Department of Agriculture, Agricultural Research Service, Foreign Disease-Weed Science Research Unit, Ft. Detrick, MD 21702; and seventh author: California Department of Food and Agriculture, 3294, Meadowview Road, Sacramento, CA 95832-1448.

Accepted for publication 8 April 2017.

\begin{abstract}
Rathayibacter toxicus, a Select Agent in the United States, is one of six recognized species in the genus Rathayibacter and the best known due to its association with annual ryegrass toxicity, which occurs only in parts of Australia. The Rathayibacter species are unusual among phytopathogenic bacteria in that they are transmitted by anguinid seed gall nematodes and produce extracellular polysaccharides in infected plants resulting in bacteriosis diseases with common names such as yellow slime and bacterial head blight. $R$. toxicus is distinguished from the other species by producing corynetoxins in infected plants; toxin production is associated with infection by a bacteriophage. These toxins cause grazing animals feeding on infected plants to develop convulsions and abnormal gate, which is referred to as "staggers," and often results in death of affected animals. $R$. toxicus is the only recognized Rathayibacter species to produce toxin, although reports of livestock deaths in the United States suggest a closely related toxigenic species may be present. A closely related but undescribed species, Rathayibacter sp. EV, originally isolated from Ehrharta villosa var. villosa in South Africa, is suspected of producing toxin. Many of the diseases caused by Rathayibacter species occur in arid areas and the extracellular polysaccharide they produce is believed to aid in their survival between crops. For example, $R$. "agropyri" was isolated from infected plant material after being stored for 50 years in a herbarium. Similarly, the anguinid vectors associated with these bacteria form seed galls in infected plants and are capable of surviving for very long periods of time under dry conditions. The addition of $R$. toxicus to the list of Select Agents has raised concern over its potential introduction and a realization that current diagnostic methods are inadequate to distinguish among Rathayibacter species. In addition, little is known about the Rathayibacter species and their seed gall nematode vectors present in the United States.

Additional keywords: bacteriology, ecology and epidemiology, etiology, nematology.
\end{abstract}

Rathayibacter toxicus (Riley and Ophel 1992) Sasaki et al. 1998 was listed as a Plant Pathogen Select Agent under 7 CFR 331 by the U.S. Department of Agriculture (USDA) Animal and Plant Health Inspection Service in 2008 (Murray et al. 2015). Relatively few plant pathologists would have known of this bacterial plant pathogen prior to its listing as a Select Agent, and fewer still would know that there are five other described species of Rathayibacter that cause similar diseases and have similar life cycles in other grass hosts. What is it about this Gram-positive bacterium that makes it such a threat to be considered a Select Agent? R. toxicus is transmitted by seed gall nematodes (Anguina sp.), some of which

Corresponding author: T. Murray; E-mail address: tim.murray@wsu.edu

This article is in the public domain and not copyrightable. It may be freely reprinted with customary crediting of the source. The American Phytopathological Society, 2017. are quarantine pests, to nearby host plants where it causes a bacteriosis disease of leaves and floral structures of several different grass species, but primarily annual ryegrass (Lolium rigidum Gaud.). During colonization, $R$. toxicus produces corynetoxins that can result in fatal poisoning of animals that graze on diseased plants, a syndrome now referred to as annual ryegrass toxicity (ARGT). To further complicate the relationship, Bird et al. (1980) and Stynes and Bird (1983) postulated the involvement of a bacteriophage in toxin production. In Australia, this cross-domain pathogen has caused plant disease on over 10 million hectares with losses due to ARGT in 2010 estimated at \$37 million USD (Carslake 2006; Kessell 2010). The potential for damage to the U.S. livestock industry resulted in listing of $R$. toxicus as a Select Agent in 2008 and relisting in 2012. The National Plant Disease Recovery System (NPDRS) subsequently developed a recovery plan for this pathogen (Murray et al.2015). None of the other five described Rathayibacter species have been shown to produce toxins in planta, although reports exist of livestock poisonings in the United States and 
elsewhere after animals grazed on pastures where seed gall nematodes were present (Cunningham and Hartley 1959; Galey et al. 1997; Galloway 1961; Haag 1945; Jensen 1961; Kurochkina and Chizhov 1980; Shaw and Muth 1949).

This review will examine the literature relevant to the history and biology of Rathayibacter broadly because they represent a fascinating group of cross-domain pathogens that frequently occur in arid areas (Fig. 1A). As such, both the pathogens and their vectors have developed specialized mechanisms for anhydrobiotic survival, namely production of extracellular polysaccharides (EPS) (Fig. 1B and C) and the formation of galls (Fig. 2A and B), in many of these diseases. Readers primarily interested in $R$. toxicus are directed to the reviews by McKay and Ophel (1993), Riley et al. (2014), and the NPDRS Recovery Plan (Murray et al. 2015), which discuss the relevant literature and provide recommendations for control and surveillance.

\section{ANNUAL RYEGRASS TOXICITY}

In 1956, Fisher (1977) received samples of annual ryegrass (L. rigidum) from veterinary officers with the South Australia Department of Agriculture that were taken from a pasture where sheep had died after feeding on the grass. Fisher found seed gall nematodes present in the sample and, while visiting the field 2 years later, observed symptoms of bacterial head blight, which he attributed to a Corynebacterium species. Nematode seed galls picked from the sample and fed to laboratory mice resulted in the death of one with symptoms similar to those of the dead sheep. By 1967 , increases in the numbers of sheep dying annually and affected properties in South Australia were great enough that funds were obtained to begin new research on the problem at the Waite Agricultural Institute (Fisher 1977).

McIntosh et al. (1967) were the first to conclude that a toxin was present where sheep were dying after feeding on infested pastures. They surveyed nine farms where staggers occurred and sampled grass from four of them. Samples were identified to plant species, evaluated for presence of Anguina agrostis (Steinbuch 1799) Filipjev 1936, separated into seed and stalk fractions for guinea pig feeding trials, and bulk samples were collected from one property for sheep feeding trials. Postmortem examinations also were conducted on animals that died of staggers from farms and feeding trials. They found that all pastures contained Wimmera ryegrass (L. rigidum) and had generally high nematode infestations. One such pasture with $21 \%$ infected seed had the greatest sheep mortality. Experimentally, sheep that grazed on one of the infested pastures developed symptoms typical of staggers and died, as did guinea pigs fed bacteria-infected seed. All had postmortem symptoms including uncoordinated movement and tetanic spasms that were consistent with those of animals that died of staggers described previously. McIntosh et al. (1967) could not conclusively demonstrate whether the toxicity was due to the nematode or the bacterium, but concluded that both were associated with ryegrass staggers. Lanigan et al. (1976) followed-up this research with animal feeding studies and concluded that the bacterial galls and not the nematode galls were the source of toxicity.

Gwynn and Hadlow (1971) expanded the reports of toxicity to sheep grazing on Wimmera ryegrass to include pastures in Western Australia. They noted that the disease had occurred in four of the six previous years in one particular pasture. Berry and Wise (1975) coined the term Wimmera rye grass toxicity, or WRGT, for the syndrome in animals associated with grazing pastures infested with seed gall nematodes and bacteria and noted that there were 58 outbreaks on 26 farms with over 3,300 dead sheep and 46 cattle. Up to $60 \%$ of the ryegrass sampled from the 26 farms was infected with both Anguina sp. and Corynebacterium sp. (now Rathayibacter), neither of which were identified to species.

Bryden et al. (1991) described the occurrence of a syndrome known as flood plain staggers (FPS) in cattle and sheep in New South Wales, Australia. Samples of blown grass (Agrostis avenacea C.C. Gmelin) were collected and used in feeding studies that resulted in animals developing symptoms similar to ARGT. Like ARGT, a nematode and Clavibacter sp. (now Rathayibacter) were found in seed heads, and a corynetoxin was extracted from the bacterial galls (Cockrum and Edgar 1985). Davis et al. (1995) later reported that 1,722 cattle, 2,466 sheep, and 11 horses on 31 different properties died as a result of FPS through April 1991. During the same year, Finnie (1991) described a corynetoxin poisoning of sheep in South Australia that was associated with annual beard grass

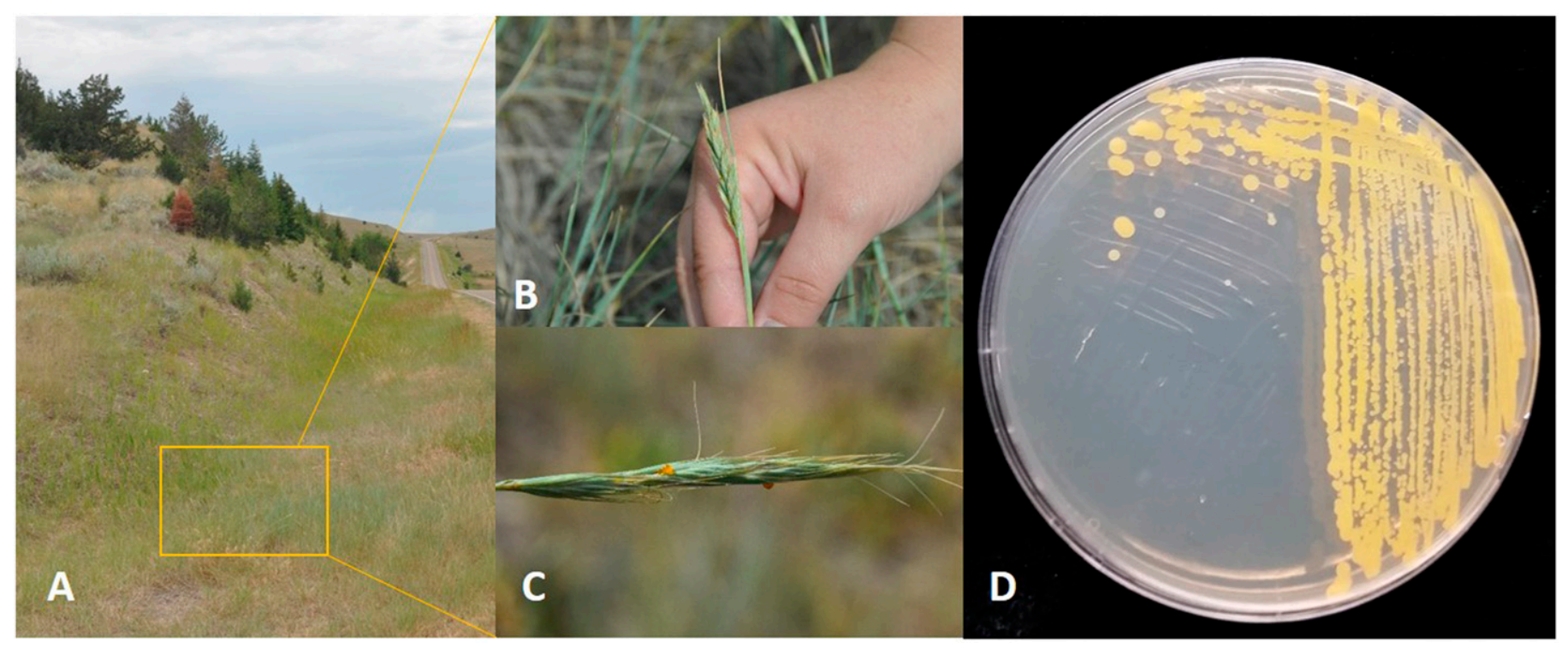

FIGURE 1

Typical habitat and symptoms of bacterial head blight of wheat grass (Agropyron sp.) collected in Idaho and Montana, and colony characteristics of the pathogen. A, Overview of roadside collection site with box showing the collection area, B, infected wheat grass head, C, close-up showing droplets of dried ooze (extracellular polysaccharide) on infected wheat grass head, and D, yellow-pigmented colonies of Rathayibacter "agropyri" growing on nutrient broth yeast extract agar. 
(Polypogon monspeliensis (L.) Desf.) and referred to it as Stewart's range syndrome (SRS) (McKay et al. 1993). According to Finnie (1991), the syndrome was indistinguishable from ARGT and had been known for about 20 years; Anguina sp. nematodes and corynetoxins were confirmed present in the sample from South Australia. McKay et al. (1993) conclusively demonstrated that Clavibacter toxicus was present in both Agrostis avenacea and P. monspeliensis and thus responsible for both FPS and SRS; however, they also demonstrated that the nematode present in these grasses was a new species and not the same one present in annual ryegrass.

Schneider (1981) noted the occurrence of ARGT in South Africa in two different districts. In one, Caledon, sheep grazed on a pasture composed of oats, ryegrass and vetch or fed hay harvested from the pasture developed symptoms consistent with ARGT and died. In the other, Bredasdorp, cattle deaths occurred on three different farms; in all cases, cattle had grazed on mixed pastures containing Italian (L. multiflorum Lam.) and/or annual ryegrass, among other plant species. Examination of hay or plant samples from each of the four pastures revealed the presence of seed gall nematodes identified as Anguina agrostis, and a pale yellow, Gram-positive bacterium identified as Corynebacterium sp. was isolated. Feeding trials with hay collected from some of the pastures and separated by plant species confirmed the toxicity was associated with the ryegrass and not the other species present.

Grewar et al. (2009) described an outbreak of ARGT in horses in the Western Cape Province of South Africa, near Ceres and within $10 \mathrm{~km}$ of one of the cattle outbreaks previously reported by Schneider (1981). In this case, horses were fed oat hay contaminated with annual ryegrass; morbidity was limited to two pastures. The

\section{FIGURE 2}

A, Yellowish bacterial galls and $\mathbf{B}$, dark nematode galls in an inflorescence of Sporobolus cryptandrus (Torr.) A. Gray with bacterial head blight collected in Idaho. diagnosis was based on symptomatology of affected animals and the presence of bacterial galls in hay fed to the horses.

Nogawa et al. (1997) reported an outbreak of annual ryegrass intoxication in cattle and sheep in Japan. In this case, animals from farms were fed oat hay contaminated with annual ryegrass imported from Australia. ARGT was confirmed after detection of corynetoxins in seed from the hay and feeding studies where cattle developed symptoms consistent with the syndrome.

\section{OTHER ANIMAL POISONINGS}

Several reports have appeared describing poisonings of grazing animals outside Australia with similarities to ARGT, but the presence of a toxigenic bacterium has not been confirmed in any of those cases. In 1941, Mullins (1941) described a disease of sheep, cattle, and horses in New Zealand known as ryegrass staggers because it was found mostly in animals that had grazed on pastures containing predominately ryegrass. Cunningham and Hartley (1959) documented three cases of staggers that occurred in 1957. They were unable to determine the cause of the disease, which occurred during autumn months, but believed it was associated with a toxin of unknown origin in the perennial ryegrass (Lolium perenne L.). No subsequent reports of annual ryegrass toxicity-like incidents are found from New Zealand.

Several reports of animal poisonings in the United States with similarities to ARGT have appeared. Haag (1945) reported mortality of sheep in Oregon that had consumed screenings of Chewings fescue (Festuca rubra subsp. commutata Gaud.). He obtained and fed screenings from the same lot to rats and showed that the material

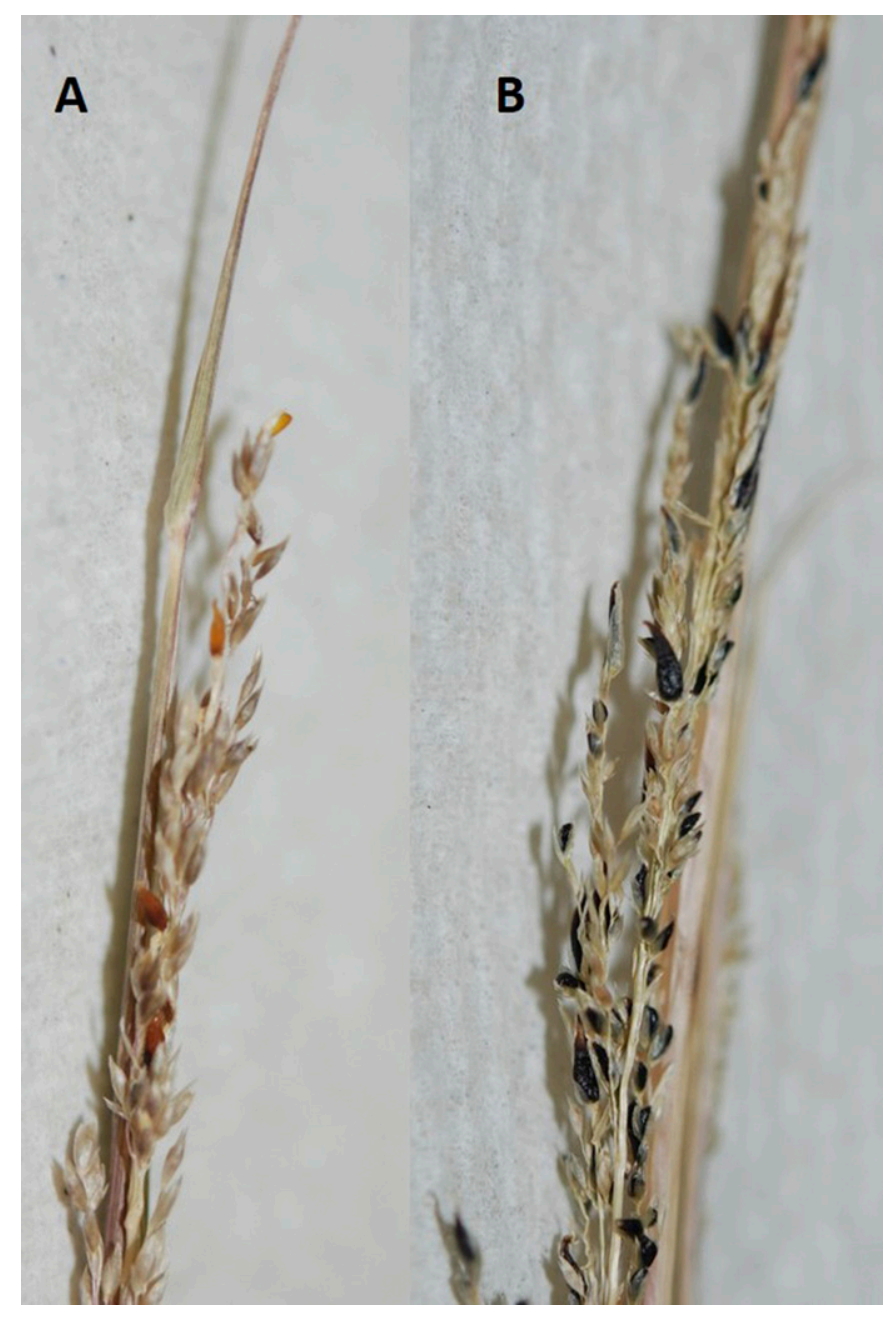


was highly toxic. Symptoms included paralysis of rear quarters with swelling and discoloration of rear legs and extensive tissue hemorrhages. Haag (1945) tested several other lots of screenings, confirmed their toxicity to rats, and concluded there was a strong causal relationship between toxicity and Anguina agrostis seed gall nematode infestation.

Shaw and Muth (1949) described several cases of cattle and sheep poisonings in Oregon after feeding on various plants including perennial rye (L. perenne), pea vine silage, and Chewings fescue screenings. Animals fed on the latter exhibited nervous system symptoms including falling, trembling, and incoordination. Feeding studies of sheep with the fescue screenings resulted in symptomatology and mortality similar to animals that fed on infested pastures. Anguina agrostis was present in up to $20 \%$ of the seed screenings. The cause of mortality was not confirmed, but presence of the nematode had the strongest association.

Jensen (1961) reported the occurrence and distribution of the grass seed nematode (Anguina agrostis) infecting several bentgrass species, Chewings fescue, and orchard grass in Oregon. He also mentioned the occurrence of livestock poisonings in animals fed Chewings fescue screenings containing nematode galls, and attributed it to the combined relationship between the nematode, a bacterium, and the host plant. However, there was no mention of isolation or characterization of the bacterium.

Galloway (1961) described three cases of livestock poisoning associated with feeding Chewings fescue seed screenings from a single farm in Oregon. Toxicity was associated with the presence of heavy infestation of Anguina sp. seed gall nematode. Two types of galls were noted in the hay; a brownish one that contained nematode larvae and another that contained a "yellow cheesy material" from which a Gram-positive bacterium resembling Corynebacterium sp. was isolated. Feeding studies conducted with chickens and rats using hay extract and pellets made from the nematode-infested hay demonstrated that toxicity was associated with an alcohol-soluble substance (Galloway 1961). Kurochkina and Chizhov (1980) in Russia reported animal poisoning after feeding on seed galls of Anguina agrostis from Agrostis sp. and suggested an association with $R$. toxicus or a related bacterium producing similar toxins.

Galey et al. (1997) described the occurrence of "staggers" in cattle in the central valley of California. Incidence ranged from 5 to $50 \%$ of animals, and the clinical course and syndrome resembled flood plain staggers. Investigation of three ranches where the losses occurred revealed the pastures did not contain perennial grasses usually associated with staggers, but they did contain other annual grasses including ryegrass. There was no mention of examining the grasses for seed gall nematodes or bacterial head blight.

Riley et al. (2004a) examined bacterial galls from old Chewings fescue samples produced in New Zealand and New Jersey and concluded that the most likely cause of the livestock symptoms was the presence of corynetoxin-like toxins produced by a variant of $R$. toxicus. This conclusion was based on (i) detection of $R$. toxicus in galls from New Zealand, but not the United States, using a monoclonal antibody specific for R. toxicus; (ii) detection of corynetoxin-like chemicals by enzyme-linked immunosorbent assay (ELISA) and high-performance liquid chromatography (HPLC) in galls from both New Zealand and the United States, and in vitro inhibition of an enzyme specifically inhibited by corynetoxins and related tunicaminyluracil antibiotics by extracts of each sample (Jago et al. 1983); and (iii) the toxin mixture in both samples was very similar, but differed from that typical of R. toxicus galls (Anderton et al. 2004).

\section{THE RATHAYIBACTER SPECIES}

Investigations of bacterial head blight of grasses, their causal agents, and the vectors involved with them, now known as Rathayibacter spp. and Anguina or Afrina spp. (B. L. BarrantesInfante, B. K. Schroeder, S. A. Subbotin, and T. D. Murray, unpublished data), respectively, began in 1897 when Emerich Ráthay described bacteriosis disease of orchard grass (Dactylis glomerata L.) in Germany and associated a bacterium with it (Ráthay 1899; Smith 1914). Rathayibacter species historically were placed in Corynebacterium (Collins and Bradbury 1986), and later in Clavibacter (Davis et al. 1984). The genus Corynebacterium originally contained Gram-positive, bacilliform-shaped bacteria (Fig. 3A) with 2, 4-diaminobutyric acid (DAB) in their cell walls (Carlson and Vidaver 1982; Collins and Bradbury 1986; Zgurskaya et al. 1993); however, since this was a heterogeneous genus (Carlson and Vidaver 1982; Dye and Kemp 1977; Starr et al. 1975), Davis et al. (1984) proposed establishing the genus Clavibacter for the Gram-positive, DAB-containing plant-pathogenic bacteria (Zgurskaya et al. 1993). Plant pathogenicity was considered a distinguishing characteristic of the bacteria. Based on morphological and physiological characteristics including menaquinone composition, along with phylogenetic analyses resulted in placement of some coryneform species in separate genera (Stackebrandt et al. 1988). Zgurskaya et al. (1993) subsequently proposed moving species that contain B2 $\gamma$ peptidoglycan with DAB in the cell wall (Sasaki et al. 1998), have MK-10 as the major menaquinone, phosphotidylglycerol

\section{FIGURE 3}

Scanning microscopic photo of $\mathbf{A}$, Rathayibacter "agropyri" and $\mathbf{B}$, infective juvenile of a seed gall nematode covered by Rathayibacter sp. (CA32). A and $\mathbf{B}$, Scale bars $=1$ and $20 \mu \mathrm{m}$.
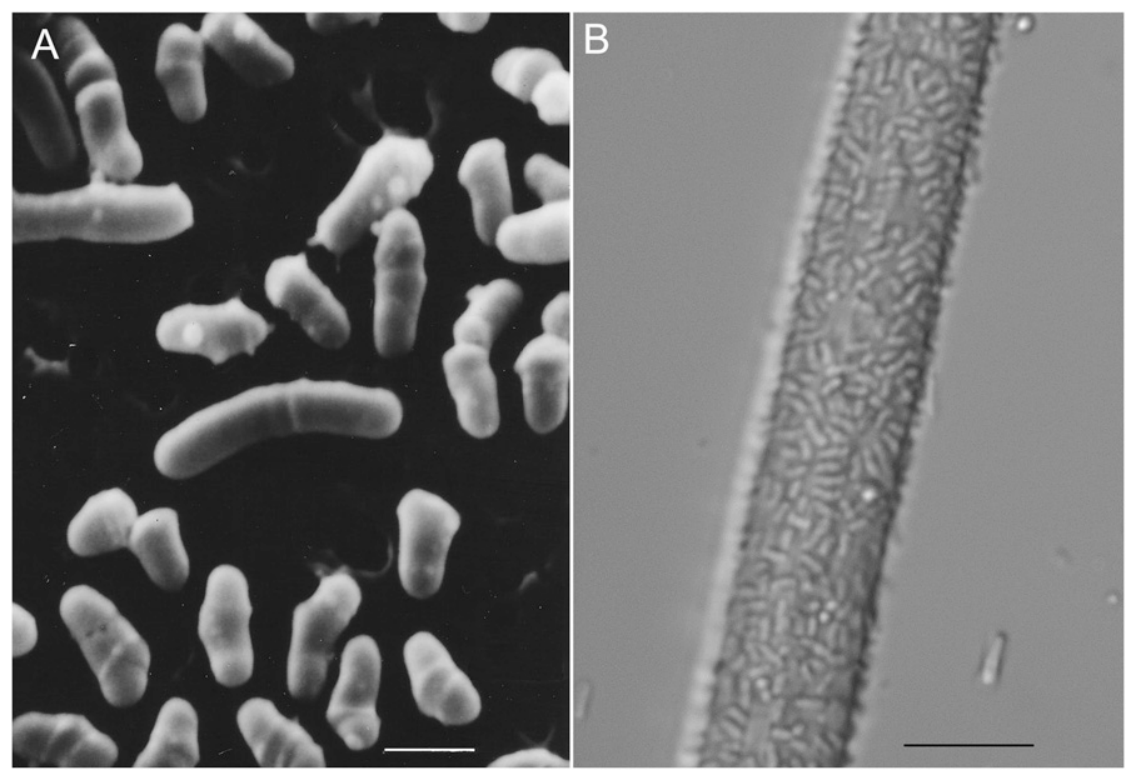
and diphosphotidylglycerol as the major phospholipids, saturated anteiso-15:0, anteiso-17:0, and iso-16:0 as the major branched fatty acids, and rhamnose and mannose as the major cell wall sugars to the genus Rathayibacter.

The genus Rathayibacter currently contains six valid species: $R$. rathayi (Smith 1913) Zgurskaya et al. 1993; $R$. tritici (Carlson and Vidaver 1982) Zgurskaya et al. 1993; R. iranicus (Carlson and Vidaver 1982) Zgurskaya et al. 1993; $R$. toxicus; $R$. caricis Dorofeeva et al. 2002; and $R$. festucae Dorofeeva et al. 2002. Three other species have been identified but not validly described: $R$. "agropyri" (B. K. Schroeder, W. L. Schneider, D. G. Luster, A. Sechler, and T. D. Murray, unpublished data), Rathayibacter sp. EV (Riley et al. 2004b), and Rathayibacter sp. TV (Vasilenko et al. 2016). All Rathayibacter species identified and described to date are vectored by plant parasitic nematodes, a feature unusual among phytopathogenic bacteria.

$R$. toxicus occupies a basal position in the genus phylogeny and it is most distinct from the other species based on the 16S rRNA gene sequence (Fig. 4) (Dorofeeva et al. 2002; Wellington 2009). Based on preliminary data, we expect additional Rathayibacter species to be described in the near future (B. K. Schroeder, W. L. Schneider, D. G. Luster, A. Sechler, and T. D. Murray, unpublished data) (Starodumova et al. 2014) (Fig. 3).

Rathayibacter rathayi. Ráthay (1899) initially discovered cocksfoot grass, also known as orchard grass, exhibiting gummosis near Vienna in 1897, but never observed similar symptoms on other grass species growing in the vicinity of the infected plants. He described affected plants as being somewhat stunted and covered with a thick, lemon-yellow bacterial slime on the uppermost stems and leaves, and inflorescences (Smith 1914), a symptom associated with many of the diseases caused by bacteria in this genus. Many organisms were isolated from the slime including fungi and a bacterium with lemon-yellow colonies. Although Ráthay inoculated seedlings and mature orchard grass plants without producing infection, he was convinced that the bacterium caused the disease. Smith (1913) later described the causal bacterium as Aplanobacter ráthayi in honor of Ráthay's pioneering work (Smith 1914); it is the type species for Rathayibacter (Burkholder 1948). This disease, commonly referred to as Rathay's disease, was frequently found throughout the European continent and England and is associated with seed as a source of inoculum (Dowson and d'Oliveira 1935). Rathay's disease is present and increasing in frequency in Oregon (Alderman et al. 2003, 2005).

Rathayibacter "agropyri”. Around the same time as Ráthay's work, O'Gara (1915) described a bacterial disease of western wheatgrass (Agropyron smithii Rydb.) in the Salt Lake Valley, Utah with similar characteristics to those described on orchard grass by Ráthay (1899). He subsequently described the bacterium as Aplanobacter agropyri, suggesting yellow gum disease as the common name. O'Gara (1916) noted the absence of symptoms on other grass species in mixed stands and speculated that the bacterium may be spread by insects. In 1980, with no known type strain in existence and the inability to distinguish it from $R$. rathayi (syn. Corynebacterium rathayi), R. "agropyri" (syn. Corynebacterium agropyri) was not included on the Approved List of Bacterial Names (Skerman et al. 1980). Cultures resembling R. "agropyri" were isolated in 1982 from grass samples collected in the 1940s and 1950s and from a sample of wheatgrass with yellow EPS (Fig. 1D) collected in Montana in 1986 (Murray 1986). These cultures, which were stored at the Washington State University Mycological Herbarium, Pullman, WA, were recently characterized physiologically and molecularly. The name $R$. "agropyri" has been proposed to reestablish it as a valid species (B. K. Schroeder, W. L. Schneider, D. G. Luster, A. Sechler, and T. D. Murray, unpublished data).

Rathayibacter tritici. Hutchinson (1917) described a bacterial disease (hereafter referred to as head blight) of wheat in the Punjab of India that resembled the diseases described by Ráthay and O'Gara, and which was known locally as tannan or tandu (also known as tundu). The disease was known prior to 1908, but was not of major concern because it affected a small percentage of plants within fields. Based on comments by D. Milne, economic botanist

\footnotetext{
FIGURE 4

Phylogenetic relationships within phytopathogenic Rathayibacter species (isolate, GenBank accession number): Bayesian 50\% majority rule consensus tree from two runs as inferred from the analysis of the 16S rRNA gene sequence alignment under the GTR + I + G model. Posterior probabilities equal to, or more than, $60 \%$ are given for appropriate clades. Strains used in the analysis include the following: $R$. "agropyri" strain CA-4, $R$. caricis, $R$. festucae, $R$. iranicus, $R$. rathayi, Rathayibacter sp. TV strain VKM Ac-2596, R. toxicus (D84127), R. tritici, Rathayibacter $\mathrm{sp}$ Leaf296, Rathayibacter sp. EV strain FH238, Rathayibacter sp. strain CA36, and Rathayibacter sp. strain CA32. The outgroups were Agromyces brachium, Agromyces rhizospherae, and Agro-
} myces ramosus.

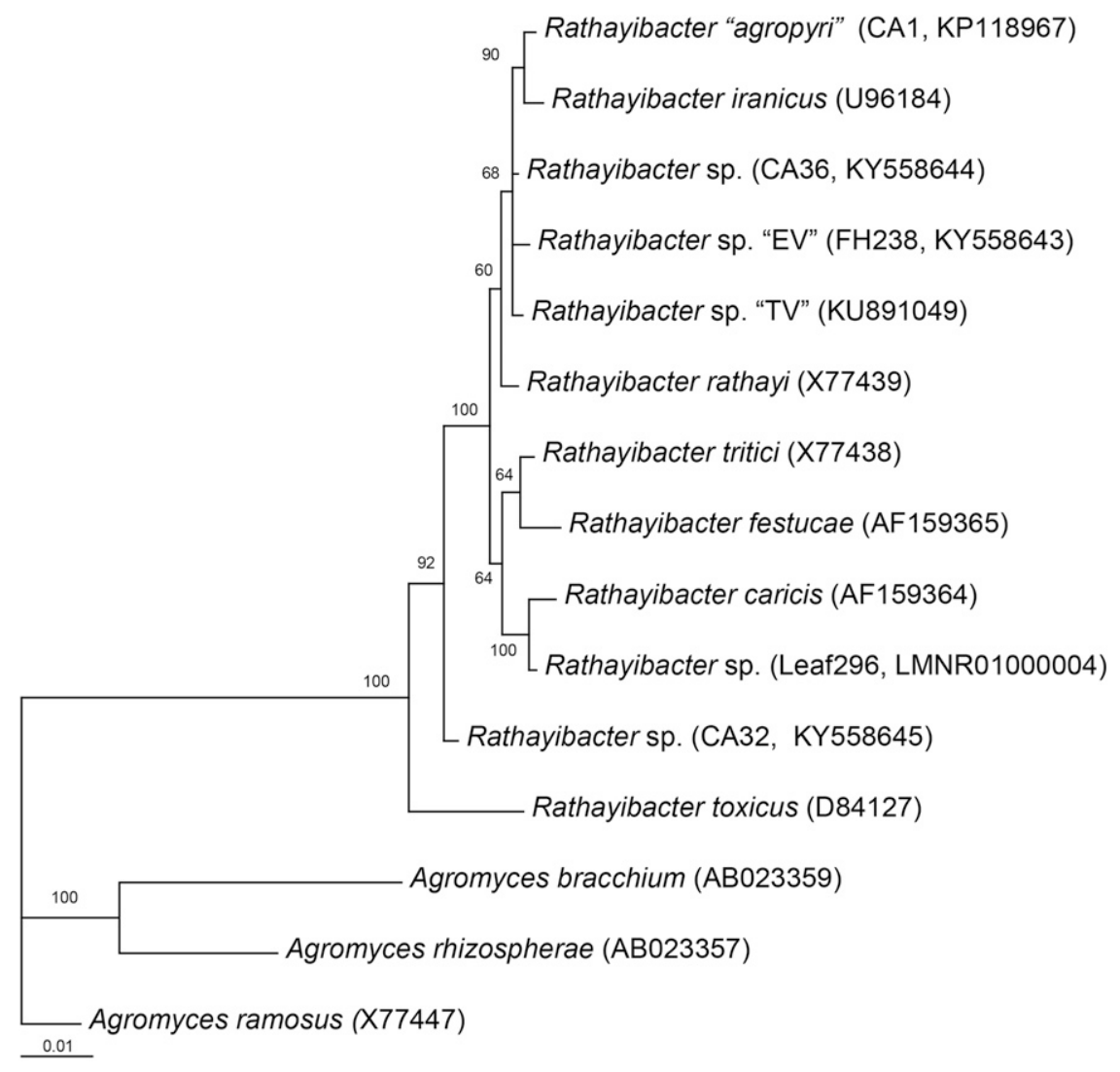


in the Punjab at that time, Hutchinson noted the possible association of head blight with "eelworm" (nematode) damage, since it only occurred in areas of the field where they occurred. Hutchinson (1917) described the bacterium as Bacterium tritici (syn. Pseudomonas tritici), but was unable to successfully infect plants with the bacterium. Milne (1919) later described earcockle disease of wheat caused by the nematode Tylenchus scandens $(=T$. tritici; now Anguina tritici (Steinbuch 1799) Chitwood 1935). He noted that some plants infected with the nematode had distorted heads and produced a slimy yellowish substance, but did not mention a bacterium associated with it.

Fahmy and Mikhail (1925) described the occurrence and distribution of head blight of wheat caused by Pseudomonas tritici in Egypt. It was first reported to them in 1919, but was likely present before and believed to be introduced to Egypt on seed from India. Based on a survey in 1923, Fahmy and Mikhail (1925) observed that affected fields often were in close proximity to one another and that damage within fields was clustered in patches. They also observed that the disease did not spread aerially between fields since healthy and diseased fields were sometimes adjacent to one another, which led them to consider seed as the source of infection. Fahmy and Mikhail (1925) described the early symptoms of the disease as wrinkled or twisted leaves appearing on lower leaves on the wheat plant with a bright yellow gummy substance now known to be EPS exuding from these impacted plant structures. As the EPS dried, it became a solid, almost clear droplet on the plant surface (Fig. 1C). Fahmy and Mikhail (1925) further described the association of head blight with nematode damage (Tylenchus tritici) and demonstrated experimentally that the nematode was required to carry the bacterium into the plant for infection, although experimental conditions and data were not presented.

Carne (1926) described the occurrence of earcockle and head blight of wheat caused by Pseudomonas tritici in Western Australia. He noted that earcockle was first reported in 1898, but that head blight was not previously known in Western Australia. He also observed that earcockle did not form on plants with head blight, suggesting that nematodes were the agent of their own destruction. Based on field experiments, Carne (1926) concluded that the nematodes do not travel more than a few inches from the galls in soil and that the bacteria require the nematode to be carried into the plant and cause disease.

Rathayibacter iranicus. $R$. iranicus was originally isolated from diseased wheat heads in Iran exhibiting symptoms characteristic of Rathayibacter infection of grass heads (Scharif 1961). The bacterium was isolated from the honey-yellow slime from aborted ovaries within infected wheat grains, but had discrepancies in physiological characteristics compared with $R$. rathayi (Corynebacterium rathayi) (Burkholder 1948, Dowson 1942; Sabet 1954), R. "agropyri" (Corynebacterium agropyri) (O'Gara 1915, 1916), and $R$. tritici (Burkholder 1948); consequently, it was described as a new species, Corynebacterium iranicum (Scharif 1961), now $R$. iranicus (Zgurskaya et al. 1993). This pathogen appears to be extremely limited in geographic distribution, having only been identified on wheat in Iran in 1961 and more recently in Turkey in 2009 (Postnikova et al. 2009).

Rathayibacter toxicus. Bird and Stynes (1977) concluded that the bacterial pathogen associated with ARGT belonged to the Corynebacterium rathayi, Corynebacterium agropyri, and Corynebacterium tritici group based on colony color and symptomatology on the host plant, but there wasn't enough data for a full comparison and species designation. Although presumptively referred to as Corynebacterium rathayi in many reports (Riley 1987), Riley and Ophel (1992) described the bacterium as Clavibacter toxicus sp. nov. based on serological properties, allozyme electrophoretic mobility, bacteriophage sensitivity, adhesion to seed gall nematodes, biochemical tests, DNA base composition, and growth factor requirements. Zgurskaya et al.
(1993) later erected the genus Rathayibacter and transferred Corynebacterium iranicus, Corynebacterium rathayi, Corynebacterium tritici, and six strains isolated from annual grasses in Australia that resembled Clavibacter toxicus to it. Sasaki et al. (1998) subsequently proposed $R$. toxicus comb. nov. on the basis of cell wall peptidoglycan content.

Rathayibacter caricis. $R$. caricis was isolated from the phyllosphere of Carex sp. growing in the Central Chernozem Nature Park, Belgorod region, Russia (Dorofeeva et al. 2002). Although R. caricis was not found to be associated with any nematodes in this habitat, their association cannot be excluded. A potential vector for this bacterium could be Heteroanguina caricis (Solovyova and Krall 1983) Chizhov and Subbotin 1985, which induces leaf galls on several Carex species and is widely distributed in Estonia, Latvia, and Lithuania, as well as several regions of Northwest Russia. Recently, Starodumova et al. (2014) reported $R$. caricis from leaf galls induced by Mesoanguina picridis (Kirjanova 1944) Chizhov \& Subbotin 1985 in Acroptilon repens (L.) DC. from Uzbekistan.

Rathayibacter festucae. R. festucae was isolated and described by Dorofeeva et al. (2002) from small leaf galls on Festuca rubra L. infected by the nematode Anguina graminis (Hardy 1850) Filipjev 1936, collected in the Moscow region of Russia. This nematode parasitizes several Festuca species in Europe and northwestern European part of Russia.

Rathayibacter sp. EV. Rathayibacter sp. EV was reported in 2004 by Riley et al. (2004b), who observed gummosis and leaf galls caused by Anguina woodi Swart et al. 2004 on Ehrhata villosa Schult. f. var. villosa in South Africa. The bacterium isolated from these plants was identified as a species of Rathayibacter based on physiological characteristics. However, DNA analysis of the bacteria demonstrated only $70 \%$ homology with genomic DNA from other Rathayibacter species, suggesting the isolate was a new species. The bacterium adheres to juveniles of Anguina woodi, the leaf gall nematode of E. villosa var. villosa, but not to Anguina funesta or Anguina tritici (Riley et al. 2004b). Interestingly, in planta production of toxin was detected in a bioassay and this work suggests that the bacterium is a unique and previously undescribed species currently referred to as Rathayibacter sp. EV (Riley et al. 2004b).

Rathayibacter sp. TV. Rathayibacter sp. TV was isolated from leaves of Tanacetum vulgare L. infected with nematodes in the Main Botanical Garden, Moscow, Russia, and a draft genome sequence of this undescribed species was released in 2016 (Vasilenko et al. 2016). Although it had $99.6 \% 16 \mathrm{~S}$ rRNA gene sequence similarity with $R$. rathayi, $R$. iranicus, and $R$. tritici, the results from matrixassisted laser desorption ionization-time of flight mass spectra clustering and multilocus phylogenetic analysis $(g y r \mathrm{~B}, r e c \mathrm{~A}, r p o \mathrm{~B}$, and $p p k$ ) suggested that it was a novel species (Vasilenko et al. 2016). This was the first report of a Rathayibacter species associated with the foliar nematode Aphelenchoides fragariae (Ritzema Bos 1891) Christie 1932, which belongs to the nematode order Aphelenchida, family Aphelenchoididae, whereas all other previously known nematode vectors of Rathayibacter species belong to the order Tylenchida, family Anguinidae. This is significant because Aphelenchoides fragariae is an important parasite of several agricultural crops and numerous ornamentals with worldwide distribution.

Even though it is uncommon for a phytopathogenic bacterium to be vectored by a nematode, it should be noted that Rathayibacter species are not the only bacteria inhabiting nematode galls (Evtushenko et al. 1994). Several other members of the family Microbacteriaceae have been characterized and described: Leifsonia poae (Evtushenko et al. 2000) from root galls induced by the grass root gall nematode Subanguina radicicola (Greeff 1872) Paramanov 1968 on Poa annua L. (Evtushenko et al. 2000); Agreia bicolorata Evtushenko et al. 2001 and Agreia spp. from leaf galls induced by Heteroanguina graminophila Evtushenko et al. 2001 on narrow reed grass, Calamagrostis neglecta (Ehrh.) Gaertn., B. Mey. 
\& Scherb. (Evtushenko et al. 2001; Starodumova et al. 2015); and three undescribed species of Plantibacter isolated from plant galls induced by Anguina agrostis, Aplanobacter agropyri Kirjanova 1955, and Mesoanguina picridis (Evtushenko and Takeuchi 2006).

\section{NEMATODE VECTORS}

The gall-forming nematodes of the subfamily Anguininae are obligate, highly specialized plant parasites that induce galls in various plant organs. Over 40 nominal species of gall-forming nematodes have been described. Three species, Anguina tritici, Anguina agrostis, and Anguina funesta, induce seed galls on some cereals and grasses, and are considered of economic importance as agricultural and quarantine pests in some countries (Chizhov and Subbotin 1990; Krall 1991). Several Anguina species are currently recognized as vectors of Rathayibacter species. Rathayibacter tritici and $R$. iranicus are exclusively associated with Anguina tritici; R. toxicus with Anguina funesta and Anguina paludicola Bertozzi \& Davies 2009 (Bertozzi and Davies 2009; McKay et al. 1993; Riley and Ophel 1992); R. rathayi with Anguina sp. parasitizing Dactylis glomerata L. (Hardison 1945); and R. festucae with Anguina graminis. Cross-inoculation experiments and in vitro adhesion tests revealed that Anguina australis Steiner 1940, Anguina tritici and an Anguina sp. from Holcus lanatus L. are potential vectors of some strains of R. toxicus (Riley 1992; Riley and McKay 1990; Riley et al. 2001).

Little is known about the relationships between the Rathayibacter sp. and anguinid nematodes. Based on current information, these relationships should not be considered mutually beneficial since nematodes do not always remain viable in bacterial galls. Infective juvenile nematodes carry bacteria on their cuticle (Fig. $3 B$ ) in a film of water from galls resting on the soil surface to the growing points of a nearby young plant. The juvenile nematode (Fig. 5A) enters developing ovules, where they induce seed gall formation that the bacteria later colonize. Results of experiments

\section{FIGURE 5}

Light microscopic photo of $\mathbf{A}$, infective juvenile and $\mathbf{B}$, female of seed gall nematode parasitizing Sporobolus cryptandrus in Idaho. Scale bar $=50 \mu \mathrm{m}$. and observations suggest that the bacteria are not able to invade plants in the absence of nematodes, but advantages of the bacteria to the nematodes are not evident; in fact, they may be negative. For example, juvenile nematodes with attached bacteria moved significantly slower than nematodes without attached bacteria and thus, have a lower chance of successfully invading a plant (Bird and Riddle 1984).

Anguina funesta and Anguina paludicola are the two known natural nematode vectors of $R$. toxicus. The seed gall nematode Anguina funesta was first described in 1973 as Anguina lolli in the Ph.D. thesis by Price, and later named Anguina funesta when it was formally described (Price et al. 1979b). Anguina funesta was considered a synonym of Anguina agrostis by several authors; however, Powers et al. (2001) and Subbotin et al. (2004) examined relationships within Anguina using internal transcribed spacer (ITS) rRNA gene sequences and concluded that Anguina funesta was clearly different from Anguina agrostis and other described species and, thus, the validity of species was confirmed. Anguina funesta induces seed galls in the ovaries of some Festuca, Lolium, and Vulpia species (Price et al. 1979b; Riley 1995), but only L. rigidum and V. myuros (L.) C.C. Gmel. are known as hosts from natural infestations. ARGT is most common in South Australia and Western Australia, but also occurs in New South Wales. It spread to South Africa, most likely in infested seed from Australia, but did not spread as quickly or have as much economic impact (Subbotin and Riley 2012). Recently, Anguina funesta was also found in Oregon (Meng et al. 2012).

The life cycle of Anguina funesta is typical of other seed gall nematodes having one generation per year. The second stage juveniles (Fig. 5A) become dormant in drying galls, which drop to the soil surface near as plants senesce and survive anhydrobiotically until the following season. With rain, juveniles rehydrate, regain activity, and invade nearby plants. The juveniles congregate at the meristem of infested tillers and wait for ovary initiation before initiating a gall by invading the ovary and modifying its development.

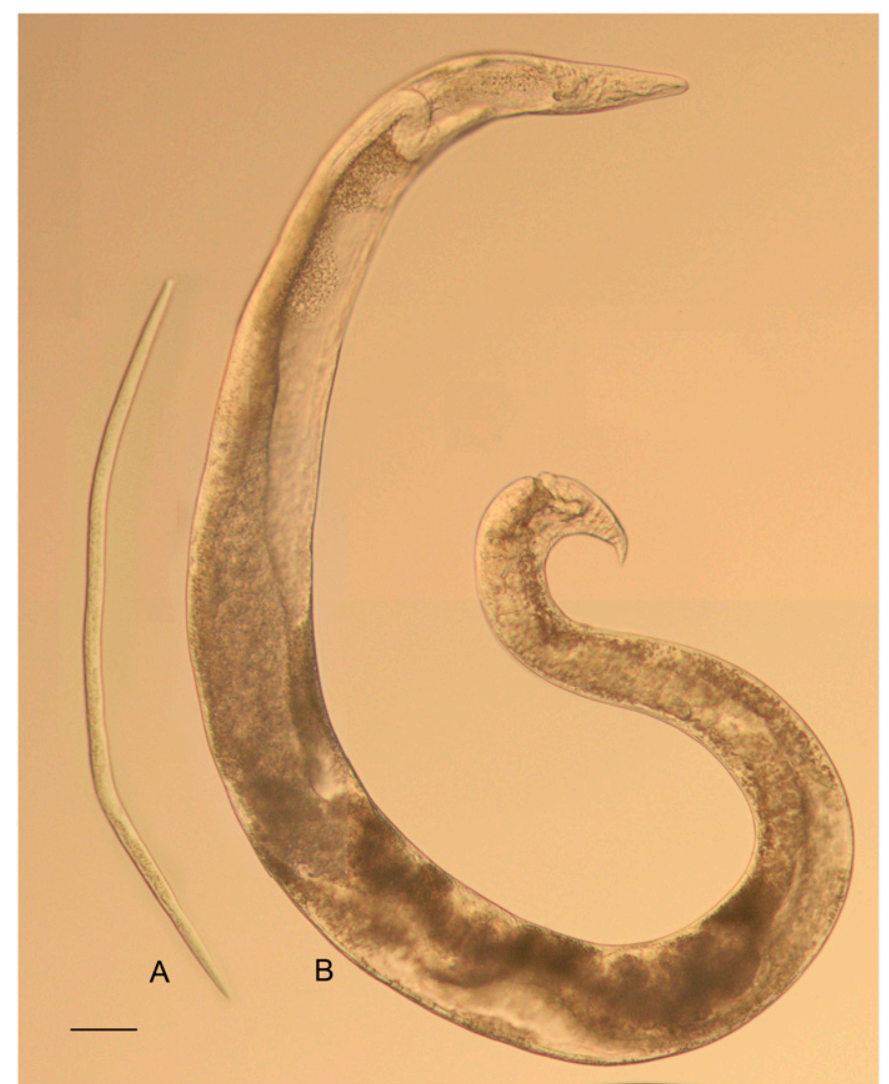


Within the gall, second stage juveniles feed and molt through two further juvenile stages to become adults (Fig. 5B) (Riley and Barbetti 2008). Females and males usually range from a few up to 20 per gall (Riley and Bertozzi 2004). Each female can produce nearly 1,000 eggs (Price et al. 1979a, b). The nematodes develop to second stage juveniles inside the eggs and then hatch in the gall. The freshly hatched juveniles cannot survive desiccation, but mature physiologically to become the survival state as the host senesces and desiccates (Riley and Barbetti 2008).

Anguina paludicola, another seed gall nematode vectoring R. toxicus, was described by Bertozzi and Davies (2009) from two hosts: its type host, the nonnative grass Polypogon monspeliensis, and a native Australian grass, Lachnagrostis filiformis (Forst.) Trinius from areas subject to occasional seasonal flooding in South Australia and New South Wales. The life cycle and relationship of Anguina paludicola is similar to that of Anguina funesta but with some differences that represent adaptations for survival in ecosystems subject to seasonal inundation (Bertozzi and McKay 1995; Davis et al. 1995; McKay et al. 1993; Riley and Barbetti 2008).

\section{SURVIVAL POTENTIAL}

The production of gummosis or bacterial slime is associated with symptoms resulting from infection by Rathayibacter. This gummosis is EPS, composed of homopolysaccharides and heteropolysaccharides secreted by the bacteria (Donot et al. 2012; Leigh and Coplin 1992). It is associated with the cell wall, forming a capsule, or it may become detached, forming a slime layer (Coplin and Cook 1990; Denny 1995; Fett 1993). R. "agropyri" was isolated in 1982 from samples stored at the Washington State University Mycological Herbarium, Pullman, WA that were collected in the 1940s and 1950s (Murray 1986). This is the longest known survival of bacteria on a plant sample and it is hypothesized that survival was facilitated by the encapsulation of $R$. "agropyri" in the dried EPS, which enables the bacteria to withstand fluctuating environmental conditions (Boles et al. 2004; Franklin et al. 2011).

The seed gall nematode vectors of Rathayibacter spp. feed and reproduce within the developing ovaries of plant seeds and overwinter in seed galls as anhydrobiotic juveniles or adults. This dormant stage can survive within the seed gall for many years. For example, Anguina tritici did not lose its ability to invade wheat seedlings after 32 years of dormancy (Limber 1973). In this dehydrated state, nematodes are more tolerant to extreme environmental conditions than are their hydrated counterparts. The second stage juveniles of Anguina agrostis in seed galls survived exposure up to $155^{\circ} \mathrm{C}$ for $5 \mathrm{~min}$, higher than that recorded for any other metazoan (Eisenback et al. 2013).

\section{TOXIN PRODUCTION}

The production of toxin in forage grasses is the result of a complex interaction between Rathayibacter species, a seed-gall nematode, a susceptible host, and potentially a bacteriophage. To date one species, $R$. toxicus, has been definitively shown to produce toxin, and two other species, $R$. iranicus and Rathayibacter sp. EV, are suspected toxin producers. The infection cycle begins when the bacterium adheres to the cuticle of compatible juvenile nematodes it encounters in the soil, and is carried to the growing point of the forage grass by the nematode (Riley and McKay 1990). The nematode initiates gall production as a natural part of the life cycle and $R$. toxicus competes with the nematode for the gall. The trigger for toxin production is unknown, but toxin generally appears late in the growing season as seeds are senescing. Senesced seeds dry and fall to the ground with galls colonized by bacteria to repeat the disease cycle.

The toxins produced by $R$. toxicus, referred to as corynetoxins, are a mixture of chemically related glycolipids belonging to the tunicamycin group of nucleoside antibiotics (Eckardt 1983) that prevent $\mathrm{N}$-linked glycosylation resulting in cell death. The exact mechanisms of toxin production remain unknown, but related systems in the Actinomycetes such as Streptomyces chartreusis Leach et al. 1953, S. clavuligerus Higgens and Kastner 1971, and Actinosynnema mirums Hasegawa et al. 1978 synthesize tunicamycin in a multistep biosynthetic pathway involving uridine, UDPGlcNAc, and at least five enzymes (Price and Tsvetanova 2007; Wyszynski et al. 2010).

Previous reports implicate corynetoxin production in $R$. toxicus with the presence of a bacteriophage (Ophel et al. 1993). Stynes and Bird (1983) originally identified a bacteriophage commonly associated with $R$. toxicus by using electron microscopy. Initial reports indicated that adding the bacteriophage (NCPPB 3778) to cultures of $R$. toxicus consistently resulted in the production of tunicamycin (Ophel et al. 1993). However, later work identified toxin-producing cultures of $R$. toxicus devoid of the bacteriophage (Kowalski et al. 2007). The ultimate role of bacteriophage infection in $R$. toxicus toxin production in nature remains to be determined, although it should be noted that a counterpart phage has not been identified for R. iranicus or Rathayibacter sp. EV system. It is unclear whether toxin production is a product of the phage, the bacteria, or an interaction/combination of the two. A complete genome sequence of the phage is available, but no genes related to toxin production were identified as part of the phage DNA (W. Schneider, A. Sechler, and E. Rogers, unpublished data).

The evolutionary drivers of developing and maintaining toxin production in $R$. toxicus are also unclear. Tunicamycin serves as a very effective nematicide, but most members of the genus are able to overcome nematodes and usurp galls without toxin production. In addition, there is a fitness cost to toxin production, as $R$. toxicus cultures grow slower while producing tunicamycin (Ophel et al. 1993). The toxin may serve multiple purposes, acting as a weapon against competing bacteria and other microorganisms, while also eliminating nematodes from galls. However, this strategy appears to be limited to R. toxicus and possibly R. iranicus and Rathayibacter sp. EV. The triggering of toxin production by the bacteriophage is also interesting. In this case the bacteriophage may have evolved a mechanism for triggering toxin production to increase the success of its primary obligate host.

\section{DETECTION AND DIAGNOSTICS FOR BACTERIA NEMATODE, AND TOXIN}

Methods for specifically detecting $R$. toxicus in infested plants have been published (see below), and several full genomic sequences are available in open access databases. However, the Select Agent status and associated scarcity of biological samples has hampered the validation of a diagnostic assay for official confirmation of the presence of the pathogen in the United States.

Sampling. As with most field-oriented plant pathogen diagnostic methods, the primary challenges are in sampling and sample preparation. $R$. toxicus infests forage grasses that may be spread across several acres; samples may consist of hay or seed from areas where symptomatic animals are identified. The most common methods used in Australia involve soaking seed, infested grass or hay samples in water or buffer and recovering live bacteria for subsequent analyses. The degree of infestation influences the sensitivity of the diagnostic assay. Larger samples result in less certainty with regard to diagnosis of the causal agent.

Morphological and biochemical traits. Like most bacteria, Rathayibacter spp. can be identified to the genus level by a combination of morphological characters, cell wall components and carbon substrate utilization (Burkholder 1948; Evtushenko and Takeuchi 2006; Zgurskaya et al. 1993). Further distinction may be achieved for some species by including specific traits such as salt 
intolerance (Riley and Ophel 1992), bacteriocin production (Gross and Vidaver 1979) and vancomycin resistance (inferred by presence of vanA gene) (Postnikova et al. 2017) (A. Sechler, unpublished data). Rathayibacter spp. are not difficult to isolate, but grow slowly, and in general more rapid methods are required for diagnosis in order to respond quickly to a disease outbreak.

Nucleic acid-based assays: Bacteria. Although time-consuming, amplified fragment length polymorphism (Agarkova et al. 2006) and PCR-16S rRNA-RFLP (Lee et al. 1997) analyses have been used to characterize the phylogeny of Clavibacter and Rathayibacter, and could be used to identify Rathayibacter spp. More rapid assays using methods such as PCR are preferred to accommodate smaller sample size and the ability to rapidly and accurately screen large numbers of samples. Rathayibacter spp. can be identified by PCR of 16S rRNA genes from samples containing live bacteria, followed by sequencing and searches against gene databases. A PCR assay based on the $R$. toxicus $16 \mathrm{~S}$ rRNA region V9 and bacteriophage NCPPB 3778 sequence analysis was developed for detection of $R$. toxicus and the associated phage (Kowalski et al. 2007). However, only one other species in the genus, $R$. tritici, was used to test whether the target sequence was unique to $R$. toxicus. PCR/mass spectrometry was applied to detect and identify multiple species of plant pathogenic bacteria, including $R$. iranicus, $R$. rathayi, $R$. tritici, and $R$. toxicus (Postnikova et al. 2008). More recently, real-time PCR primers and probes were described to identify the same species from grasses and grains (Postnikova et al. 2017).

The analysis of vancomycin resistant protein vanA, CRISPRassociated protein $c s e 4$, secA ATPase, chromosome partition protein SMC, tRNA dihydrouridine synthase, and cysteine desulfurase genes and inter-simple sequence repeats allowed identification of three population groups of $R$. toxicus (Arif et al. 2016). Sequences of the $g y r \mathrm{~B}, r e c \mathrm{~A}, r p o \mathrm{~B}$, and $p p k$ genes also could be useful for identification of Rathayibacter species (B. K. Schroeder, W. L. Schneider, D. G. Luster, A. Sechler, and T. D. Murray, unpublished data) (Starodumova et al. 2014; Vasilenko et al. 2016).

Nucleic acid-based assays: Nematode. Diagnosis of the gallforming nematodes based on morphological and morphometrical characters is difficult, time consuming, and requires significant expertise. Powers et al. (2001) and Subbotin et al. (2004) molecularly characterized agriculturally important anguinid species and showed the ITS rRNA gene could serve as a reliable marker for identification of this nematode group. Powers et al. (2001) also showed that PCRITS1-RFLP using AluI, BsrI, EcoRI, HaeIII, HhaI, HinfI, and TaqI could clearly distinguish Anguina agrostis, Anguina funesta, Anguina pacificae Cid del Prado Vera \& Maggenti 1984, Anguina tritici, A. agropyronifloris Norton 1965, Anguina microlanae (Fawcett 1938) Steiner 1940, Afrina wevelli van den Berg 1985, and several unidentified species from one another. Later, PCR-ITS1-RFLP and sequencing of this gene region was used to confirm the presence of Anguina funesta in Oregon (Meng et al. 2012). Ma et al. (2011) developed TaqMan real-time PCR methods for detection of second stage juveniles of Anguina agrostis. Using the ITS rRNA gene fragment, Li et al. (2015) developed and validated TaqMan real-time PCR methods for detection of Anguina agrostis, Anguina funesta, Anguina tritici, and Anguina pacificae. Although all these protocols enable fast and accurate identification of these species, comparative sequence analysis of the ITS region should be considered as the main approach if test results are inconclusive.

Immunoassays: Bacteria. An ELISA for detection of $R$. toxicus was developed against a surface antigen from the bacterium with subsequent improvements to sampling and streamlining the assay (Masters et al. 2006; 2011). A semiquantitative ELISA protocol was later developed for improved risk evaluation (Masters et al. 2014). The ELISA protocols and improvements have been applied to identify pastures at high-risk for ARGT, and to screen exports in Australia since 1996. The monoclonal antibodies raised against the $R$. toxicus antigen were screened for specificity against $R$. tritici,
R. rathayi, $R$. michiganense subsp. insidiosum (sic: Clavibacter michiganensis subsp. insidiosus), and Corynebacterium agropyri (R. "agropyri"). The improved immunoassay for $R$. toxicus in hay (Masters et al. 2011) is used by Diagnostics and Laboratory Services, Biosecurity and Regulation Department of Agriculture and Food, Western Australia (DAFWA) and the laboratories at the South Australian Research and Development Institute (SARDI) (A. Masters, personal communication).

Immunoassays: Corynetoxins. Although the corynetoxin (tunicamycin antibiotic) responsible for ARGT can be identified and detected through chemical analyses such as HPLC and mass spectrometry, these techniques are expensive, time-consuming, and require large and impractical amounts of sample material. A standardized protocol using ELISA was developed with monoclonal antibodies raised against conjugated tunicamycin for more rapid and sensitive toxin identification in hay and veterinary samples (Than et al. 2002). However, this assay is not currently in use by any government.

\section{DISEASE MANAGEMENT}

It is theoretically possible to control ARGT at any level of the interaction: grazing animal, grass species, nematode, or bacterium (Fisher 1977). It is generally not practical to apply nematicides or antibiotics to large grazing areas to control the nematode or bacterium directly. In an attempt to immunize animals against tunicamycin toxicity, researchers at the CSIRO Division of Animal Health in Australia injected sheep with tunicamycin conjugated to a carrier protein (Than et al. 1998). Although the treatment provided protection against ARGT after consumption of contaminated seed heads in approximately $90 \%$ of vaccinated animals, this vaccine does not appear to have been commercialized. Likewise, an antidote was developed, but never commercialized (Riley et al. 2014); in both cases the practicality of administering the treatment and their effectiveness against high doses of toxin were questionable. Furthermore, the need for control measures has declined over the past 30 years due to a decline in ARGT outbreaks, largely owing to success of past management practices including deployment of the antagonist Dilophospora alopecuri (Fr.) Fr. (Riley 1994).

Currently used control measures focus on preventing ryegrass seed maturation by applying herbicide, mowing and/or heavy grazing immediately after head emergence, prior to seed set and maturation when tunicamycin toxicity increases rapidly (https:// www.agric.wa.gov.au/livestock-biosecurity/controlling-annualryegrass-toxicity-argt-through-management-ryegrass-pasture). This approach must be followed for 2 to 3 years and combined with planting clean ryegrass seed to reduce the number of nematode and bacterial galls as well as the incidence of ARGT.

\section{LOOKING AHEAD}

Although R. toxicus is a Select Agent in the United States, the other five described Rathayibacter species remain relatively unstudied because the diseases they cause are obscure and do not have a recognized economic impact. This situation has resulted in knowledge gaps regarding the basic biology of these plant pathogens. $R$. toxicus poses a threat to U.S. agriculture because of its ability to produce corynetoxins that are lethal to grazing animals. Two other species, $R$. iranicus and the undescribed Rathayibacter sp. EV are suspected of being able to produce corynetoxins. The tunicamycin biosynthetic pathway responsible for corynetoxin production is well characterized from other bacteria, but its regulation and evolutionary role in the life cycle of $R$. toxicus is not understood. A bacteriophage was initially implicated in toxin production by $R$. toxicus, but current evidence suggests that the association is not absolute, and there is no evidence for phage involvement in toxin production by Rathayibacter sp. EV or R. iranicus. 
Little is known about the potential for toxin production by the other described Rathayibacter species. Reports of unexplained livestock poisonings in the United States leave open the possibility that $R$. toxicus or a related toxigenic Rathayibacter species may be responsible (Riley et al. 2003). These poisonings have occurred mostly in the western United States over a long period of time and do not have a clear pattern, which makes them very difficult to study. Preliminary data suggest additional species of both Rathayibacter and Anguina exist in the United States (B. L. Barrantes-Infante, unpublished data) (B. K. Schroeder, W. L. Schneider, D. G. Luster, A. Sechler, and T. D. Murray, unpublished data). Consequently, important data needed to conduct a risk analysis for establishment of $R$. toxicus or other toxigenic Rathayibacter species in the United States are missing and necessitates a need to develop a better understanding of the species of Rathayibacter and their vectors that are present in the United States. Development and validation of detection assays for $R$. toxicus and its vectors that can discriminate among the known and unknown Rathayibacter and their vectors also are needed to protect U.S. agriculture from its introduction. As new Rathayibacter and Anguina species are identified and characterized, existing detection assays need to be reevaluated to insure they remain specific for the target pathogen. It also will be necessary to determine if these new species are capable of producing corynetoxins now or if given the proper circumstances such as introduction of the corynetoxin biosynthetic gene cluster, could they produce corynetoxins? These are important questions given that the known Rathayibacter species produce similar disease symptoms in several grass species and are found in similar environments as $R$. toxicus.

\section{ACKNOWLEDGMENTS}

Financial support of grants funded by the 2008 Farm Bill, Section 10201 administered through the U.S. Department of Agriculture (USDA) Animal and Plant Health Inspection Service (13-81300247-CA and 14-8130-0367-CA) and the Emerging Research Issues Program funded by the Washington State University Agricultural Research Center are gratefully acknowledged. PPNS 0739, Department of Plant Pathology, College of Agricultural, Human, and Natural Resource Sciences, Agricultural Research Center, Hatch Project No. WNP00670, Washington State University, Pullman, WA 99164-6430. Mention of trade names or commercial products in this publication is solely for the purpose of providing specific information and does not imply recommendation or endorsement by the U.S. Department of Agriculture. USDA is an equal opportunity provider and employer.

\section{LITERATURE CITED}

Agarkova, I. V., Vidaver, A. K., Postnikova, E. N., Riley, I. T., and Schaad, N. W. 2006. Genetic characterization and diversity of Rathayibacter toxicus. Phytopathology 96:1270-1277.

Alderman, S. C., Bilsland, D. M., Griesbach, J. A., Milbrath, G. M., Schaad, N. W., and Postnikova, E. 2003. Use of a seed scarifier for detection and enumeration of galls of Anguina and Rathayibacter species in orchard grass seed. Plant Dis. 87:320-323.

Alderman, S. C., Ocamb, C. M., and Mellbye, M. E. 2005. Quantitative assessment of Anguina sp. and Rathayibacter rathayi in Dactylis glomerata seed production fields in Oregon and estimates of yield loss. Plant Dis. 89:1313-1316.

Anderton, N., Beales, K. A., Cao, Y., Colegate, S. M., Edgar, J. A., Michalewicz, A., Riley, I. T., Stewart, P. L., and Than, K. A. 2004. The identification of corynetoxin-like tunicaminyluracil-glycolipids from nematode galls in Festuca nigrescens from North America and New Zealand. Pages 204-209 in: Poisonous Plants and Related Toxins. T. Acamovic, C. S. Stewart, and T. W. Pennycott, eds. CAB International, Wallingford, UK.

Arif, M., Busot, G. Y., Mann, R., Rodoni, B., Liu, S., and Stack, J. P. 2016. Emergence of a new population of Rathayibacter toxicus: An ecologically complex, geographically isolated bacterium. PLoS One 11:e0156182.

Berry, P. H., and Wise, J. L. 1975. Wimmera rye grass toxicity in Western Australia. Aust. Vet. J. 51:525-530.
Bertozzi, T., and Davies, K. A. 2009. Anguina paludicola sp. n. (Tylenchida: Anguinidae): The nematode associated with Rathayibacter toxicus infection in Polypogon monspeliensis and Lachnagrostis filiformis in Australia. Zootaxa 2060:33-46.

Bertozzi, T., and McKay, A. C. 1995. Incidence on Polypogon monspeliensis of Clavibacter toxicus and Anguina sp., the organisms associated with 'flood plain staggers' in South Australia. Aust. J. Exp. Res. 35:567-569.

Bird, A. F., and Riddle, D. L. 1984. Effect of attachment of Corynebacterium rathayi on movement of Anguina agrostis larvae. Int. J. Parasitol. 14:503-511.

Bird, A. F., and Stynes, B. A. 1977. The morphology of a Corynebacterium sp. parasitic on annual rye grass. Phytopathology 67:828-830.

Bird, A. F., Stynes, B. A., and Thomson, W. W. 1980. A comparison of nematode and bacteria-colonized galls induced by Anguina agrostis in Lolium rigidum. Phytopathology 70:1104-1109.

Boles, B. R., Thoendel, M., and Singh, P. K. 2004. Self-generated diversity produces "insurance effects" in biofilm communities. Proc. Natl. Acad. Sci. USA 101:16630-5.

Bryden, W. L., Irwin, C. E., Davis, E. O., Curran, G. L., Lean, I. J., McKay, A. C., Edgar, J. A., and Burgess, L. W. 1991. Flood plain staggers: An intoxication in cattle due to the ingestion of blown grass (Agrostis avenacea). Proc. Nutr. Soc. Aust. 16:240.

Burkholder, W. H. 1948. Genus 1. Corynebacterium Lehmann and Neumann. Pages 381-408 in: Bergey's Manual of Determinative Bacteriology, 6th ed. R. S. Breed, E. G. D. Murray, and A. P. Hitchens, eds. The Williams \& Wilkins Co., Baltimore, MD.

Carlson, R. R., and Vidaver, A. K. 1982. Taxonomy of Corynebacterium plant pathogens, including a new pathogen of wheat, based on polyacrylamide gel electrophoresis of cellular proteins. Int. J. Syst. Bacteriol. 32:315-326.

Carne, W. M. 1926. Earcockle (Tylenchus tritici) and a bacterial disease (Pseudomonas tritici) of wheat. J. Dept. Agric. W. Aust. 3:508-512.

Carslake, T. 2006. Livestock: Ryegrass toxicity. Farming Ahead 178:62-63.

Chizhov, V. N., and Subbotin, S. A. 1990. [Plant-parasitic nematodes of the subfamily Anguininae (Nematoda, Tylenchida). Morphology, trophic specialization, system.] Zool. Zh. 69:15-26 (in Russian).

Cockrum, P., and Edgar, J. 1985. Rapid estimation of corynetoxins in bacterial galls from annual ryegrass (Lolium rigidum Gaudin) by high-performance liquid chromatography. Aust. J. Agric. Res. 36:35-41.

Collins, M. D., and Bradbury, J. F. 1986. Plant pathogenic species of Corynebacterium. Pages 1276-1284 in: Bergey's Manual of Systematic Bacteriology. P. H. A. Sneath, N. S. Mair, M. E. Sharpe, and J. G. Holt, eds. Vol. 2. The Williams \& Wilkins Co., Baltimore, MD.

Coplin, D. L., and Cook, D. 1990. Molecular genetics of extracellular polysaccharide biosynthesis in vascular phytopathogenic bacteria. Mol. PlantMicrobe Interact. 3:271-279.

Cunningham, I. J., and Hartley, W. J. 1959. Ryegrass staggers. N.Z. Vet. J. 7:1-7.

Davis, E. O., Curran, G. E., Hetherington, W. T., Norms, D. N., Wise, G. A., Rothi, I. J., Seawright, A. A., and Bryden, W. L. 1995. Clinical, pathological and epidemiological aspects of flood plain staggers, a corynetoxicosis of livestock grazing Agrostis avenacea. Aust. Vet. J. 72:187-190.

Davis, M. I., Gillaspie, A. G., Vidaver, A. K., and Harris, R. W. 1984. Clavibacter: A new genus containing some phytopathogenic coryneform bacteria, including Clavibacter xyli subsp. xyli sp. nov., subsp. nov. and Clavibacter xyli subsp. cynodontis subsp. nov., pathogens that cause ratoon stunting disease of sugarcane and bermudagrass stunting disease. Int. J. Syst. Bacteriol. 34:107-117.

Denny, T. P. 1995. Involvement of bacterial polysaccharides in plant pathogenesis. Annu. Rev. Phytopathol. 33:173-197.

Donot, F., Fontana, A., Baccou, J. C., and Schorr-Galindo, S. 2012. Microbial exopolysaccharides: Main examples of synthesis, excretion, genetics, and extraction. Carbohydr. Polym. 87:951-962.

Dorofeeva, L. V., Evtushenko, L. I., Krausova, V. I., Karpov, A. V., Subbotin, S. A., and Tiedje, J. M. 2002. Rathayibacter caricis sp. nov. and Rathayibacter festucae sp. nov., isolated from the phyllosphere of Carex sp. and the leaf gall induced by the nematode Anguina graminis on Festuca rubra L., respectively. Int. J. Syst. Evol. Microbiol. 52:1917-1923.

Dowson, W. J. 1942. On the generic name of the gram positive bacterial plant pathogens. Trans. Br. Mycol. Soc. 25:311-314.

Dowson, W. J., and d'Oliveira, M. 1935. On the occurrence of Aplanobacter rathayi E. F. Smith on Dactylis glomerata in England. Ann. Appl. Biol. 22: 23-26.

Dye, D. W., and Kemp, W. J. 1977. A taxonomic study of plant pathogenic Corynebacterium species. N.Z. J. Agric. Res. 20:563-582.

Eckardt, K. 1983. Tunicamycins, streptovirudins, and corynetoxins, a special subclass of nucleoside antibiotics. J. Natural Prod. 46:544-550.

Eisenback, J. D., Wei, M., and Roane, C. W. 2013. Heat tolerance and aging of the anhydrobiotic seed gall nematode with SEM observations. J. Nematol. 45:43-48. 
Evtushenko, L. I., Dorofeeva, L. V., Cole, J. R., Subbotin, S. A., and Tiedje, J. M. 2000. Leifsonia poae gen. nov., sp. nov., isolated from nematode galls on Pоа аппиа, and reclassification of 'Corynebacterium aquaticum' Leifson 1962 as Leifsonia aquatica (ex Leifson 1962) gen. nov., nom. rev., comb. nov. and Clavibacter xyli Davis et al. 1984 with two subspecies as Leifsonia xyli (Davis et al. 1984) gen. nov., comb. nov. Int. J. Syst. Evol. Microbiol. 50:371-380.

Evtushenko, L. I., Dorofeeva, L. V., Dobrovolskaya, T. G., Streshinskaya, G. M., Subbotin, S. A., and Tiedje, J. M. 2001. Agreia bicolorata gen. nov., sp. nov., to accommodate actinobacteria isolated from narrow reed grass infected by the nematode Heteroanguina graminophila. Int. J. Syst. Evol. Microbiol. 51:2073-2079.

Evtushenko, L. I., Dorofeeva, L. V., Dobrovolskaya, T. G., and Subbotin, S. A. 1994. Coryneform bacteria from plant galls induced by nematodes of the subfamily Anguininae. Russ. J. Nematol. 2:99-104.

Evtushenko, L. I., and Takeuchi, M. 2006. The Family Microbacteriaceae. Pages 1020-1098 in: The Prokaryotes: Volume 3: Archaea. Bacteria: Firmicutes, Actinomycetes. M. Dworkin, S. Falkow, E. Rosenberg, K.-H. Schleifer, and E. Stackebrandt, eds. Springer, New York.

Fahmy, T., and Mikhail, T. 1925. The bacterial disease of wheat caused by Pseudomonas tritici Hutchinson. Agric. J. Egypt (New Ann.) Ser. 1:64-72.

Fett, W. F. 1993. Bacterial exopolysaccharides: Their nature, regulation, and role in host-pathogen interactions. Curr. Top. Bot. Res. 1:367-390.

Finnie, J. W. 1991. Corynetoxin poisoning in sheep in the south-east of South Australia associated with annual beard grass (Polypogon monspeliensis). Aust. Vet. J. 68:370.

Fisher, J. M. 1977. Annual ryegrass toxicity. Pages 7-11 in: Biennial Report of the Waite Agricultural Institute, 1976-77. University of Adelaide, Glen Osmond, South Australia.

Franklin, M. J., Nivens, D. E., Weadge, J. T., and Howell, P. L. 2011. Biosynthesis of the Pseudomonas aeruginosa extracellular polysaccharides, alginate, Pel, and Psl. Front. Microbiol. 2:1-16.

Galey, F. D., Blanchard, P. C., Adaska, J., Puschner, B., Holstege, D., McDougald, N., Garthwaite, I., Miles, C., and Whitehead, G. C. 1997. Staggers in pastured beef cattle in the central valley of California. In: Proceedings 40th American Association Veterinary Laboratory Diagnosticians. Louisville, KY.

Galloway, J. H. 1961. Grass seed nematode poisoning in livestock. J. Am. Vet. Med. Assoc. 139:1212-1214.

Grewar, J. D., Allen, J. G., and Guthrie, A. J. 2009. Annual ryegrass toxicity in thoroughbred horses in Ceres in the Western Cape Province, South Africa. J. S. Afr. Vet. Assoc. 80:220-223.

Gross, D. C., and Vidaver, A. K. 1979. Bacteriocins of phytopathogenic Corynebacterium species. Can. J. Microbiol. 25:367-374.

Gwynn, R., and Hadlow, A. J. 1971. Toxicity syndrome in sheep grazing Wimmera ryegrass in Western Australia. Aust. Vet. J. 47:408.

Haag, J. R. 1945. Toxicity of nematode infested Chewings fescue seed. Science 102:406-407.

Hardison, J. R. 1945. Bacterial blight of orchard grass observed in Oregon. Plant Dis. Rep. 29:600.

Hutchinson, C. M. 1917. A bacterial disease of wheat in the Punjab. Memoirs of the Department of Agriculture in India. Bacteriol. Ser. 1:169-175.

Jago, M. V., Payne, A. L., Peterson, J. E., and Bagust, T. J. 1983. Inhibition of glycosylation by corynetoxin, the causative agent of annual ryegrass toxicity: A comparison with tunicamycin. Chem. Biol. Interact. 45:223-234.

Jensen, H. J. 1961. Nematodes Affecting Oregon Agriculture. Oregon State University, Corvallis, OR.

Kessell, D. 2010. Annual ryegrass toxicity-Current situation. W.A. Department of Agriculture and Food, ed. Western Australian Agriculture Authority, South Perth, Western Australia.

Kowalski, M. C., Cahill, D., Doran, T. J., and Colegate, S. M. 2007. Development and application of polymerase chain reaction-based assays for Rathayibacter toxicus and a bacteriophage associated with annual ryegrass (Lolium rigidum) toxicity. Aust. J. Exp. Agric. 47:177-183.

Krall, E. L. 1991. Wheat and grass nematodes: Anguina, Subanguina, and related genera. Pages 721-760 in: Manual of Agricultural Nematology. W. R. Nickle, ed. Marcel Dekker, Inc., New York.

Kurochkina, K. G., and Chizhov, V. N. 1980. [On the toxicity of Anguina agrostis galls to animals]. IX Konferentsiya Ukrainskogo Parazitologicheskogo Obshchestva. Tezisy dokladov. VIGIS Mosc. USSR 2:206 (In Russian).

Lanigan, G. W., Payne, A. L., and Frahn, J. L. 1976. Origin of toxicity in parasitized annual ryegrass (Lolium rigidum). Aust. Vet. J. 52:244.

Lee, I.-M., Bartoszyk, I. M., Gundersen-Rindal, D. E., and Davis, R. E. 1997. Phylogeny and classification of bacteria in the genera Clavibacter and Rathayibacter on the basis of 16S rRNA gene sequence analyses. Appl. Environ. Microbiol. 63:2631-2636.
Leigh, J. A., and Coplin, D. L. 1992. Exopolysaccharides in plant-bacterial interactions. Annu. Rev. Microbiol. 46:307-346.

Li, W., Zonghe, Y., Nakhla, M. K., and Skantar, A. M. 2015. Real-time PCR methods for detection and identification of the nematodes Anguina funesta, A. agrostis, A. tritici, and A. pacificae. Plant Dis. 99:1584-1589.

Limber, D. P. 1973. Notes on the longevity of Anguina tritici (Steinbuch, 1799) Filipjev, 1936, and its ability to invade wheat seedlings after thirtytwo years of dormancy. Proc. Helminthol. Soc. Wash. 40:272-274.

Ma, Y., Xie, H., Wang, J., and Lui, C. 2011. Detection of second stage juveniles of Anguina agrostis using TaqMan real-time PCR. Russ. J. Nematol. 19:151-158.

Masters, A. M., Gregory, A. R., Evans, R. J., Speijers, J. E., and Sutherland, S. S. 2006. An enzyme- linked immunosorbent assay for the detection of Rathayibacter toxicus, the bacterium involved in annual ryegrass toxicity, in hay. Aust. J. Agric. Res. 57:731-742.

Masters, A. M., Samarasinghe, B., Kalkhoven, M. J., den Hollander, G. L., and Palmer, D. G. 2011. Improvements to the immunoassay for detection of Rathayibacter toxicus in hay. Crop Pasture Sci. 62:523-530.

Masters, A. M., Samarasinghe, B., Kalkhoven, M. J., den Hollander, G. L., and Palmer, D. G. 2014. A semi-quantitative enzyme-linked immunosorbent assay for Rathayibacter toxicus, the bacterium involved in annual ryegrass toxicity. Crop Pasture Sci. 65:1329-1334.

McIntosh, G. H., Rac, R., and Thomas, M. R. 1967. Toxicity of parasitized Wimmera ryegrass, Lolium rigidum, for sheep and cattle. Aust. Vet. J. 43: 349-353.

McKay, A. C., and Ophel, K. M. 1993. Toxigenic Clavibacter/Anguina associations infecting grass seedheads. Annu. Rev. Phytopathol. 31:151-167.

McKay, A. C., Ophel, K. M., Reardon, T. B., and Gooden, J. M. 1993. Livestock deaths associated with Clavibacter toxicus-Anguina sp. infection in seedheads of Agrostis avenacea and Polypogon monspeliensis. Plant Dis. 77:635-641.

Meng, S., Alderman, S., Fraley, C., Ludy, R., Sun, F., and Osterbauer, N. 2012. Identification of Anguina funesta from annual ryegrass seed lots in Oregon. Published Online. Plant Health Prog. doi:10.1094/PHP-2012-1024-01-RS

Milne, D. 1919. Earcockle in wheat. Bull. Dep. Agric. Punjab 1:1-5.

Mullins, J. 1941. "Staggers" in animals. N.Z. J. Agric. 62:169.

Murray, T. D. 1986. Isolation of Corynebacterium agropyri from 30- to 40year-old herbarium specimens of Agropyron species. Plant Dis. 70:378-380.

Murray, T.D., Agarkova, I., Alderman, S., Allen, J., Bulluck, R., Chitamber, J., Divan, C., Riley, I., Schroeder, B., Sechler, A., and Subbotin, S. 2015. Recovery plan for Rathayibacter poisoning caused by Rathayibacter toxicus (syn. Clavibacter toxicus). National Plant Disease Recovery System, a cooperative project of The American Phytopathological Society and The United States Department of Agriculture.

Nogawa, M., Ishikawa, T., Miyazaki, S., Suto, Y., Sato, W., Taneichi, A., and Kobayashi, M. 1997. Annual ryegrass intoxication in cattle and sheep fed oaten hay imported from Australia. J. Jpn. Vet. Med. Assoc. 50:321-326.

O'Gara, P. J. 1915. A bacterial disease of Western wheat-grass. First account of the occurrence of a new type of bacterial disease in America. Science 42: 616-617.

O'Gara, P. J. 1916. A bacterial disease of western wheat-grass, Agropyron smithii. Phytopathology 6:341-350.

Ophel, K. M., Bird, A. F., and Kerr, A. 1993. Association of bacteriophage particles with toxin production by Clavibacter toxicus, the causal agent of annual ryegrass toxicity. Phytopathology 83:676-681.

Postnikova, E., Agarkova, I., Altundag, S., Eskandari, F., Sechler, A., Karahan, A., Vidaver, A. K., Schneider, W., Ozakman, M., and Schaad, N. W. 2009. Rathayibacter iranicus isolated from symptomless wheat seeds in Turkey. Plant Pathol. 58:796.

Postnikova, E., Agarkova, I. V., Schneider, W. L., Sechler, A. J., and Riley, I. T. 2017. Detection of Rathayibacter spp. Seeds of Cereals and Grasses. In: Detection of Plant-Pathogenic Bacteria in Seed and Other Planting Material, 2nd ed. M. Fatmi, R. R. Walcott, and N. W. Schaad, eds. American Phytopathological Society, St. Paul, MN.

Postnikova, E., Baldwin, C., Whitehouse, C. A., Sechler, A., Schaad, N. W., Sampath, R., Harpin, V., Li, F., Melton, R., Blyn, L., Drader, J., Hofstadler, S., and Schneider, W. L. 2008. Identification of bacterial plant pathogens using multilocus polymerase chain reaction/electrospray ionization-mass spectrometry. Phytopathology 98:1156-1164.

Powers, T. O., Szalanski, A. L., Mullin, P. G., Harris, T. S., Bertozzi, T., and Griesbach, J. A. 2001. Identification of seed gall nematodes of agronomic and regulatory concern with PCR-RFLP of ITS1. J. Nematol. 33:191-194.

Price, N. P. J., and Tsvetanova, B. 2007. Biosynthesis of the tunicamycins: A review. J. Antibiot. 60:485-491.

Price, P. C., Fisher, J. M., and Kerr, A. 1979a. Annual ryegrass toxicity: Parasitism of Lolium rigidum by a seed-gall forming nematode (Anguina sp.). Ann. Appl. Biol. 91:359-369. 
Price, P. C., Fisher, J. M., and Kerr, A. 1979b. On Anguina funesta n. sp. and its association with Corynebacterium sp., in infecting Lolium rigidum. Nematologica 25:76-85.

Ráthay, E. 1899. Über eine Bakteriose von Dactylis glomerata L. Sitzungsberichte Akademie der Wissenschaften Wien 1899 CVIII. Band. I. bis IV. Heft. (Jahrgang 1899-Jänner bis April):597-602.

Riley, I. T. 1987. Serological relationships between strains of coryneform bacteria responsible for annual ryegrass toxicity and other plant-pathogenic corynebacteria. Int. J. Syst. Bact. 37:153-159.

Riley, I. T. 1992. Anguina tritici is a potential vector of Clavibacter toxicus. Australas. Plant Pathol. 21:147-148.

Riley, I. T. 1994. Dilophospora alopecuri and decline in annual ryegrass toxicity in Western Australia. Aust. J. Agric. Res. 45:841-850.

Riley, I. T. 1995. Vulpia myuros and the annual ryegrass toxicity organisms, Anguina funesta, and Clavibacter toxicus. Fundam. Appl. Nematol. 18: 595-598.

Riley, I. T., Allen, J. G., and Barbetti, M. J. 2014. Rathayibacter toxicus. Pages 775-786 in: Manual of Security Sensitive Microbes and Toxins. D. Liu, ed. CRC Press, Taylor \& Francis Group, Boca Raton, FL.

Riley, I. T., and Barbetti, M. J. 2008. Australian anguinids: Their agricultural impact and control. Australas. Plant Pathol. 37:289-297.

Riley, I. T., and Bertozzi, T. 2004. Variation in sex ratios in four Anguina (Nematoda: Anguinidae) species. Trans. R. Soc. S. Aust. 128:43-46.

Riley, I. T., Gregory, A. R., Allen, J. G., and Edgar, J. A. 2003. Poisoning of livestock in Oregon in the 1940s to 1960s attributed to corynetoxins produced by Rathayibacter in nematode galls in chewing fescue (Festuca nigrescens). Vet. Hum. Toxicol. 45:160-162.

Riley, I. T., Gregory, A. R., Allen, J. G., and Edgar, J. A. 2004a. Bacteria and corynetoxin-like toxins in nematode seed-galls in Festuca nigrescens from North America and New Zealand. Pages 50-55 in: Poisonous Plants and Related Toxins. T. Acamovic, C. S. Stewart, and T. W. Pennycott, eds. CAB International, Wallingford, UK.

Riley, I. T., and McKay, A. C. 1990. Specificity of the adhesion of some plant pathogenic microorganisms to the cuticle of the nematodes in the genus Anguina (Nematoda: Anguinidae). Nematology 36:90-103.

Riley, I. T., and Ophel, K. M. 1992. Clavibacter toxicus sp. nov., the bacterium responsible for annual ryegrass toxicity in Australia. Int. J. Syst. Bact. 42: 64-68.

Riley, I. T., Schmitz, A., and de Silva, P. 2001. Anguina australis, a vector for Rathayibacter toxicus in Ehrharta longiflora. Australas. Plant Pathol. 30: 171-175.

Riley, I. T., Swart, A., Postnikova, E., Agarkova, I., Vidaver, A., and Schaad, N. 2004b. New association of a toxigenic Rathayibacter sp. and Anguina woodi in Ehrhata villosa var. villosa in South Africa. (Abstr.) Phytopathology 94(suppl.):S88

Sabet, K. A. 1954. On the host range and systemic position of the bacteria responsible for the yellow slime disease of wheat (Triticum vulgare Vill.) and cocksfoot grass (Dactylis glomerata L.). Ann. Appl. Biol. 41:606-611.

Sasaki, J., Chijimatsu, M., and Suzuki, K.-I. 1998. Taxonomic significance of 2, 4-diaminobutyric acid isomers in the cell wall peptidoglycan of actinomycetes and reclassification of Clavibacter toxicus as Rathayibacter toxicus comb. nov. Int. J. Syst. Bact. 48:403-410.

Scharif, G. 1961. Corynebacterium iranicum sp. nov. on wheat (Triticum vulgare L.) in Iran, and a comparative study of it with C. tritici and C. rathayi. Entomol. Phytopathol. Appl. 19:1-24
Schneider, D. J. 1981. First report of annual ryegrass toxicity in the Republic of South Africa. Onderstepoort J. Vet. Res. 48:251-255.

Shaw, J. N., and Muth, O. H. 1949. Some types of forage poisoning in Oregon cattle and sheep. J. Am. Vet. Med. Assoc. 114:315-317.

Skerman, V. B. D., McGowan, V., and Sneath, P. H. A. 1980. Approved Lists of Bacterial Names. Int. J. Syst. Bact. 30:225-420.

Smith, E. F. 1913. A new type of bacterial disease. Science 38:926.

Smith, E. F. 1914. Ráthay's disease of orchard grass. Pages 155-160 in: Bacteria in Relation to Plant Diseases, Vol. 3. Carnegie Institution of Washington, Washington, D.C.

Stackebrandt, E., Smida, J., and Collins, M. D. 1988. Evidence of phylogenetic heterogeneity within the genus Rhodococcus: Revival of the genus Gordona (Tsukamura). J. Gen. Appl. Microbiol. 34:341-348.

Starodumova, I. P., Prisyazhnaya, N. V., Dorofeeva, L. V., and Evtushenko, L. I. 2015. Novel actinobacteria of the genus Agreia isolated from plant galls induced by plant-parasitic nematodes. Russian Immunol. J. 9(18), 2:613-615. (In Russian)

Starodumova, I. P., Prisyazhnaya, N. V., Tarlachkov, S. V., Dorofeeva, L. V., Vasilenko, O. V., and Evtushenko, L. I. 2014. Systematics of the genus Rathayibacter: From traditional approaches to genomes analysis. Pages 711 in: Materials of the 1st Pushchino School-Conference "Biochemistry, Physiology and Biosphere Role of Microorganisms," Pushchino (In Russian).

Starr, M. P., Mendel, M., and Murata, N. 1975. The phytopathogenic coryneform bacteria in the light of DNA base composition and DNA-DNA segmental homology. J. Gen. Appl. Microbiol. 21:13-26.

Stynes, B., and Bird, A. 1983. Development of annual ryegrass toxicity. Aust. J. Agric. Res. 34:653-660.

Subbotin, S. A., Krall, E. L., Riley, I. T., Chizhov, V. N., Staelens, A., De Loose, M., and Moens, M. 2004. Evolution of the gall-forming plant parasitic nematodes (Tylenchida: Anguinidae) and their relationships with hosts as inferred from internal transcribed spacer sequences of nuclear ribosomal DNA. Mol. Phylogenet. Evol. 30:226-235.

Subbotin, S. A., and Riley, I. T. 2012. Stem and gall forming nematodes. Pages 521-574 in: Practical Plant Nematology. R. H. Manzallia-Lopez and N. Marban-Mendoza, eds. Biblioteca Basica de Agricultura.

Than, K., Colegate, S., and Edgar, J. 2002. Development of a quantitative ELISA for screening fodder for corynetoxins. A report for the Rural Industries Research and Development Corporation. RIRDC Publication No 02/118. RIRDC Project No. CSA-3A.

Than, K. A., Cao, Y., Michalewicz, A., and Edgar, J. A. 1998. Development of a vaccine against annual ryegrass toxicity. Pages $165-168$ in: Toxic plants and other natural toxicants. T. Garland and A. C. Barr, eds. CAB International, Wallingford, UK.

Vasilenko, O. V., Starodumova, I. P., Tarlachkov, S. V., Dorofeeva, L. V., Avtukh, A. N., and Evtushenko, L. I. 2016. Draft genome sequence of "Rathayibacter tanaceti" strain VKM Ac-2596 isolated from Tanacetum vulgare infested by a foliar nematode. Genome Announc. 4:e00512-16.

Wellington, E. M. 2009. Actinobacteria. Pages 26-44 in: Encyclopedia of Microbiology. M. Schaechter, ed. Academic Press, Oxford, UK.

Wyszynski, F. J., Hesketh, A. R., Bibb, M. J., and Davis, B. G. 2010. Dissecting tunicamycin biosynthesis by genome mining: cloning and heterologous expression of a minimal gene cluster. Chem. Sci. (Camb.) 1:581-589.

Zgurskaya, H. I., Evtushenko, L. I., Akimov, V. N., and Kalakoutskii, L. V. 1993. Rathayibacter gen. nov., including the species Rathayibacter rathayi comb. nov., Rathayibacter tritici comb. nov., Rathayibacter iranicus comb. nov., and six strains from annual grasses. Int. J. Syst. Bacteriol. 43:143-149. 